\title{
The Effect of Brassinosteroid on Pollen Germination and Tube Growth in Three Dianthus Species
}

\author{
Aslıhan Çetinbaş Genç* \\ Department of Biology, Marmara University, Göztepe Campus, Kadıköy, 34722 Istanbul, Turkey \\ *aslihan.cetinbas@marmara.edu.tr \\ Received: 3 October 2019 \\ Accepted: 12 December 2019 \\ DOI: $10.18466 /$ cbayarfbe. 628874
}

\begin{abstract}
In this study, the effect of brassinosteroid on pollen germination and tube growth of Dianthus calocephalus, Dianthus carmelitarum, and Dianthus deltoides were investigated. Brassinosteroid treatments did not cause a significant increase in pollen germination of Dianthus calocephalus, while the pollen tube length significantly increased by $8.39 \%$ at $0.05 \mathrm{mM}, 43.75 \%$ at $0.25 \mathrm{mM}, 38.40 \%$ at $0.5 \mathrm{mM}$ and $7.30 \%$ at $2.5 \mathrm{mM}$ in compare the control. Also, brassinosteroid treatments did not cause a significant increase in pollen germination, and tube length in Dianthus carmelitanum. Although brassinosteroid treatments did not cause a significant change in pollen tube length in Dianthus deltoides, $0.05 \mathrm{mM}, 0.025$ $\mathrm{mM}$ and $0.5 \mathrm{mM}$ brassinosteroid treatments were found to have an increasing effect on pollen germination. Besides, brassinosteroid treatment did not cause a significant change in tube abnormality for all species and all concentration.
\end{abstract}

Keywords: Brassinosteroid, Dianthus, Plant bioregulators, Pollen germination, Pollen tube growth.

\section{Introduction}

Dianthus belongs to the Caryophyllaceae family containing more than 300 species that mostly grow in Asia and Europe [1]. It is one of the major medicinal plants due to the effectiveness of various disease treatments, especially cancer and also an important commercial plant due to its common use in the cosmetic industry [2]. Due to these important features, in Dianthus breeding, it is frequently essential to enlarge genetic variability to generate various species or cultivars with advanced features like high antibacterial, antifungal, cytotoxic, antioxidant, and antidiabetic compounds to provide better content for the pharmaceutical and cosmetic industry. To enlarge the genetic diversity, interspecific hybridization is noticed as one of the most beneficial offers. [3]. Pollen performance is an important parameter during the interspecific hybridization process due to the lack of pollen performance during the process reduces the success of hybridization [4]. Pollen performance can be monitored by main pollen parameters such as germination and tube length. In addition to these characters, tube abnormalities are very useful indicators to evaluate the pollen performance in detail $[5,6]$. Researchers have been described various substances as pollen performance enhancer such as inorganic ions [7], proteins [8], flavanols [9], boron [10], polyamines [11, 6], and plant hormones [12].

Brassinosteroid (BR) is natural plant hormones that have a considerable task in plant growth [13]. BR controls the very important courses like division, elongation, differentiation, nucleic acid and protein synthesis, like many other hormones [14]. Also, it has been reported by many researchers that BR encourage pollen germination and pollen tube growth, and subsequently fruit yield $[12,15,16]$. Stimulating effect of BR on pollen germination and tube growth previously reported in tomato, rice and almond $[17,18$, 19]. Also, Vogler et al [12] have stated that BR treatment induced in vitro pollen germination and tube growth in Arabidopsis. Moreover, Gökbayrak and Engin [20] have been stated that BR application increased pollen germination rate in pomegranate.

The goal of this work is to investigate the effect of different concentrations of BR on pollen performance of three Dianthus species; Dianthus calocephalus, Turkey endemic Dianthus carmelitarum and Dianthus deltoids. The result may conduce promoting the pollen efficiency by species-specific concentrations of BR may ensure beneficial knowledge for optimize pollination and increase the fruit set, mainly in commercial plants such as carnation. 


\section{Materials and Methods}

Pollen materials of D. calocephalus, $D$. carmelitarum and $D$. deltoides were collected from Istanbul/Turkey in 2019 spring. Pollen grains were germinated in $\mathrm{BK}$ medium with $\% 12$ sucrose for 3 hours at room temperature [21]. BK medium was supplemented with $0.05,0.25,0.5$ and $2.5 \mathrm{mM}$ of BR. BK medium that not contain BR was used for the control. Pollen grains with tubes twice as long as pollen diameter were considered as germinated. For each group, approximately 500 pollen grains were counted to measure the germination rates, and approximately 150 pollen tubes were measured to define the pollen tube length. Besides, curling, swelling, fluctuation, and articulation were considered as an abnormality. For each group, approximately 150 germinated pollen grains were counted to measure the abnormality rates. All preparations were analysed and photographed with KAMERAM software, using an Olympus BX-51 light microscope. Statistical analyses were performed by SPSS 16.0 software, and data were subjected to oneway analysis of variance (ANOVA) with a threshold Pvalue of 0.05 .

\section{Results and Discussion}

In order to determine the different BR concentrations on pollen performance of three different Dianthus species, pollen germination rates and tube lengths were measured. To make a more detailed comparison, tube abnormalities such as tube branching and swelling were investigated.

According to results, BR treatments did not cause a significant increase in pollen germination of $D$. calocephalus (Figure 1a). However, pollen tube length significantly increased by $8.39 \%$ at $0.05 \mathrm{mM}, 43.75 \%$ at $0.25 \mathrm{mM}, 38.40 \%$ at $0.5 \mathrm{mM}$ and $7.30 \%$ at $2.5 \mathrm{mM}$ in compare the control (Figure 1b). Besides, no significant increase in the abnormality rate of the tubes was detected (Figure 1c).

In D. carmelitanum, BR treatments did not cause a significant increase in pollen germination, tube length and abnormality rate of the tubes (Figure $2 \mathrm{a}, \mathrm{b}, \mathrm{c}$ ). Results pointed out that the applied BR concentrations have no effect on the pollen performance of $D$. carmelitanum.

In D. deltoides, $0.05 \mathrm{mM}, 0.025 \mathrm{mM}$ and $0.5 \mathrm{mM} \mathrm{BR}$ treatments were found to have an increasing effect on pollen germination, significantly (Figure 3a). However, BR treatments did not cause a significant change in pollen tube length and abnormality rate of the tubes (Figure 3b, c).

Pollen performance is an important parameter during the interspecific hybridization process due to the lack of pollen performance during the process reduces the success of hybridization [4]. Various substances improve pollen performance such as inorganic ions, proteins, plant growth regulators and, etc. [7,12]. For instance, Wu et al. [22] stated ATP encouraged pollen germination and tube growth in Nicotiana tabacum. Muhlemann et al. [23] indicated flavanols enhanced pollen tube growth in Solanum lycopersicum. Also, Çetinbaş-Genç [6] stated that putrescine stimulated pollen performance in Camellia sinensis. The most interesting of these substances that affect pollen performance is plant hormones [12]. Wu et al. [24] stated that indole acetic acid and gibberellin stimulated pollen tube growth in Torenia fournieri. Also, Chhun et al. [25] stated gibberellin coordinates pollen viability and pollen tube growth in rice.

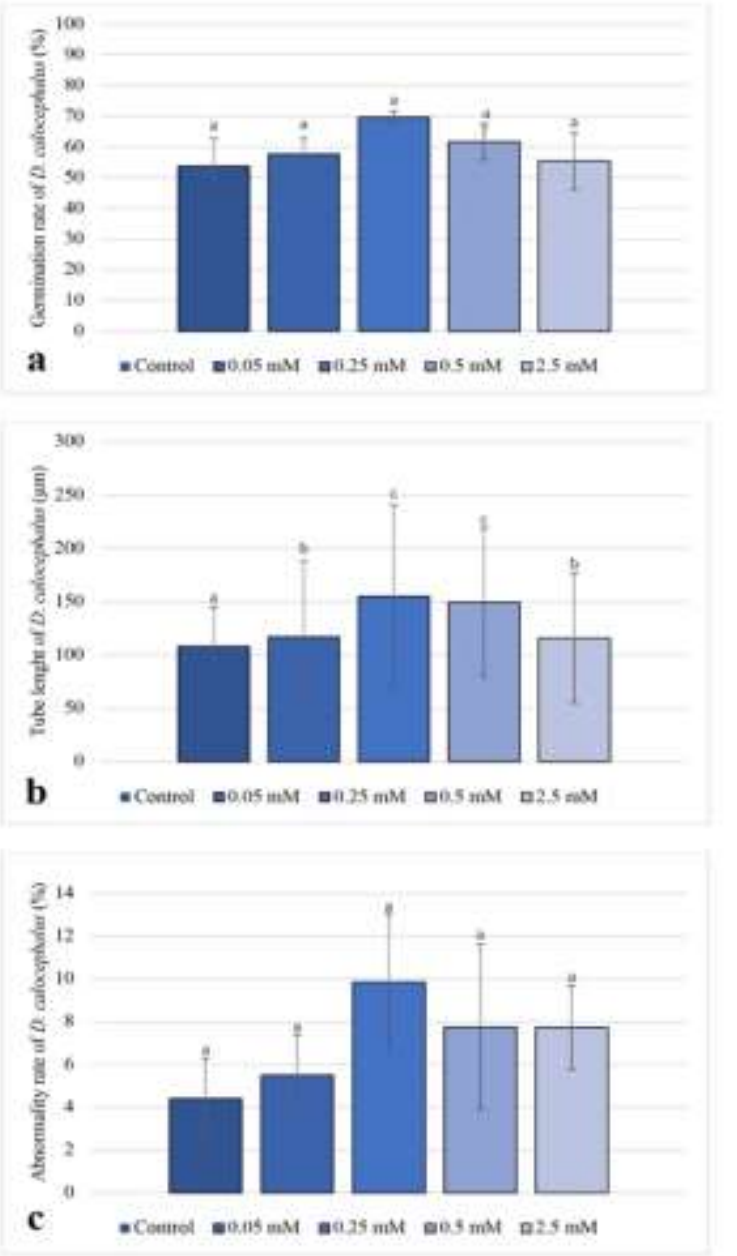

Figure 1. Pollen performance of $D$. calocephalus after BR treatmet. a. Pollen germination, b. Pollen tube length, c. Pollen tube abnormality rate. Distinct letters point out the statistically significant differences $(\mathrm{P}<0.05)$ and error bars indicate the standard deviations.

BRs are natural plant hormones accepted for their capability to support cell elongation [26]. Among the plant hormones, BRs are the least examined hormones in terms of their effects on pollen germination and tube 
growth [20]. BRs were shown to promote in vitro pollen germination and tube growth in Camellia japonica [27], Arabidopsis thaliana [12], Punica granatum [28] and Vitis vinifera [29]. According to obtained results, BR treatments promoted pollen tube length in D. calocephalus and increased germination rate (except $2.5 \mathrm{mM}$ ) in $D$. deltoides.

Researchers indicate that different chemicals can change pollen tube morphology [30]. However, BR treatment did not cause a significant change in tube abnormality for all species and all concentration. This means that when $\mathrm{BR}$ is used to improve pollen performance, there will be no damage to the morphology of the tubes.
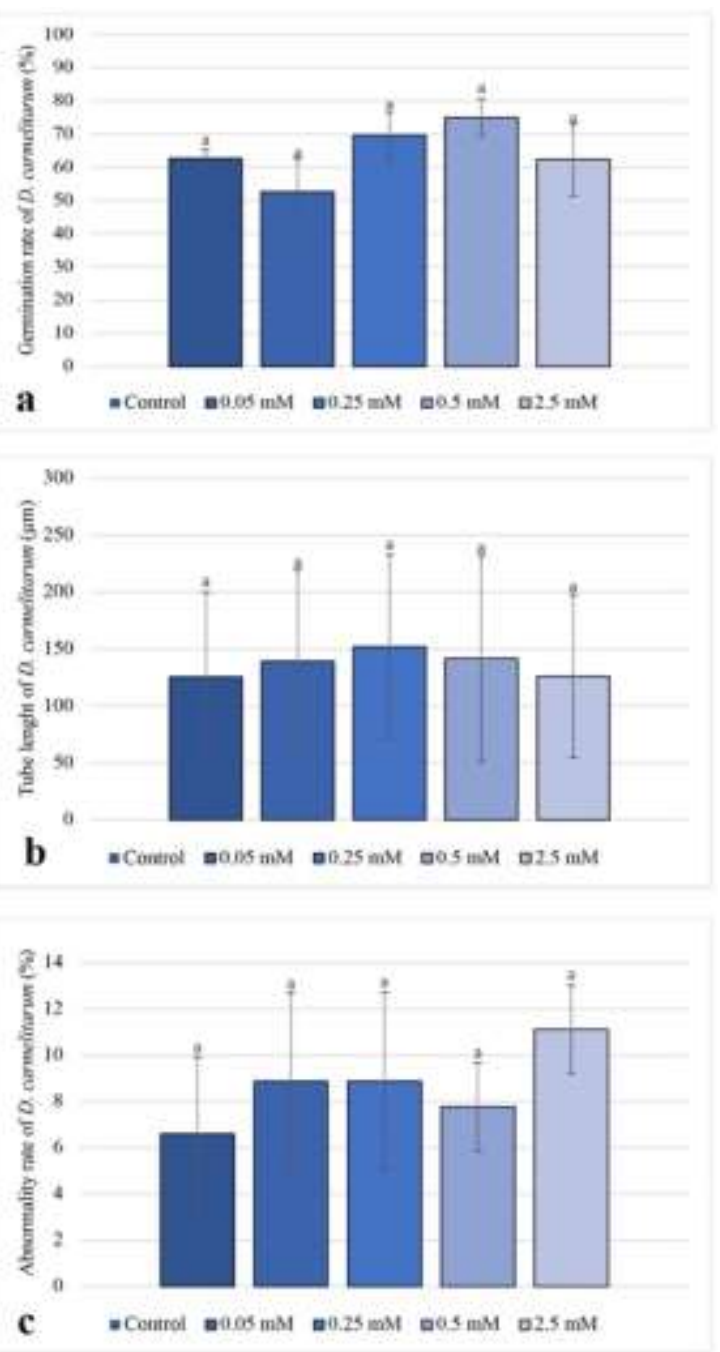

Figure 2. Pollen performance of $D$. carmelitarum after BR treatment. a. Pollen germination, b. Pollen tube length, c. Pollen tube abnormality rate. Distinct letters point out the statistically significant differences $(\mathrm{P}<0.05)$ and error bars indicate the standard deviations.

Due to the pollen grain has a specific response to some various agents such as temperature, chemical, hormones, pollen is a useful marker to investigate and the comparate the effects of various agents on the pollen of various species [31]. Favourable or adverse impacts might be diverse for the species or even for the genotypes [32]. Parallel to this situation, pollen of three Dianthus species showed distinct pollen performance under different BR treatment. For instance, the germination rate was highest after $0.25 \mathrm{mM}$ BR treatment in $D$. calocephalus, while germination rate was highest after $0.5 \mathrm{mM} \mathrm{BR}$ treatment in $D$. carmelitanum and $D$. deltoides. Also, tube length was maximum after $0.25 \mathrm{mM}$ BR treatment in $D$. calocephalus and D. carmelitarum, while tube length was maximum after $0.5 \mathrm{mM} \mathrm{BR}$ treatment in $D$. deltoides.
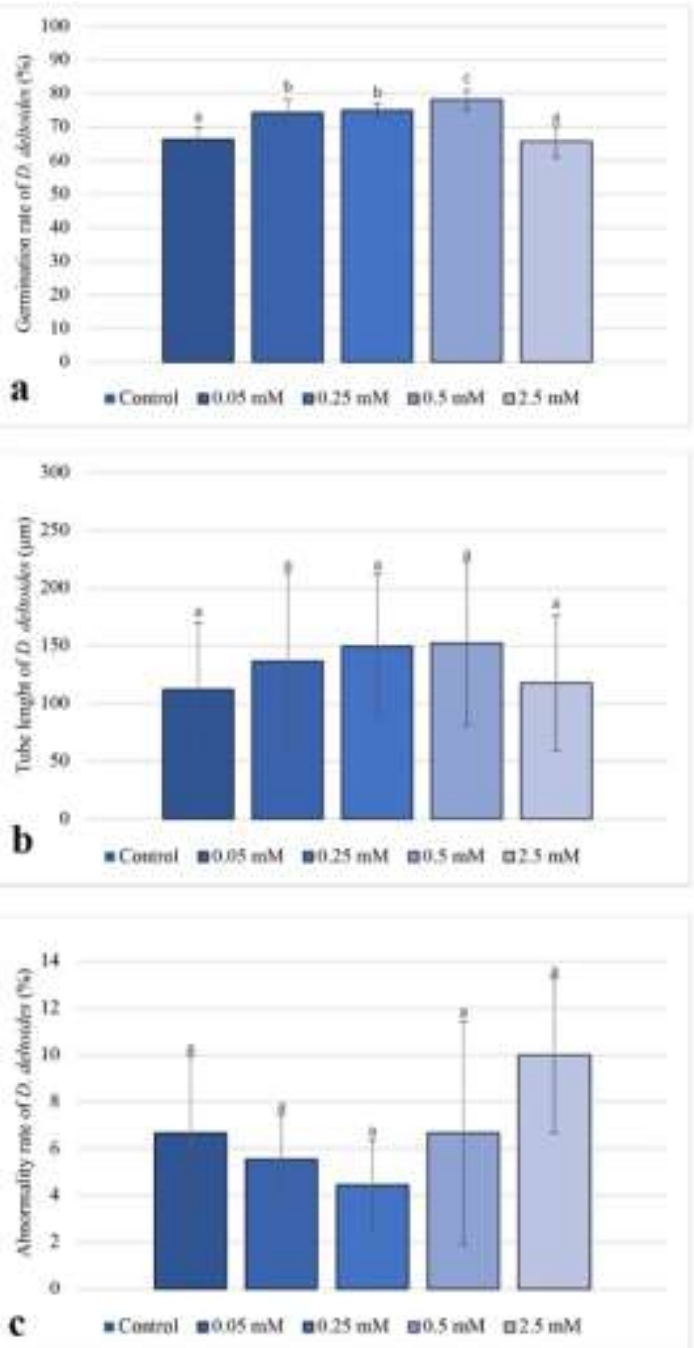

Figure 3. Pollen performance of $D$. deltoides after BR treatment. a. Pollen germination, b. Pollen tube length, c. Pollen tube abnormality rate. Distinct letters point out the statistically significant differences $(\mathrm{P}<0.05)$ and error bars indicate the standard deviations. 


\section{Conclusion}

In conclusion, BR can be used to improve pollen performance for $D$. calocephalus and $D$. deltoides.

\section{Acknowledgement}

I thank Kevser Özcan for pollen material support. Also, I thank Prof Meral Ünal, Prof Filiz Vardar and Prof Giampiero Cai for the fruitful discussion.

\section{Ethics}

There are no ethical issues after the publication of this manuscript.

\section{References}

1. Obmann, A, Werner, I, Presser, A, Zehl, M, Swoboda, Z, Purevsuren, S, Narantuya, S, Kletter, C, Glasl S. 2011. Flavonoid Cand O-glycosides from the Mongolian medicinal plant Dianthus versicolor Fisch. Carbohydrate Research; 346, 1868-1875.

2. Aliyazicioglu, R, Demir, S, Badem, M, Sener, SO, Korkmaz, N Demir, EA., Ozgen, U, Karaoglu, SA, Aliyazicioglu, Y. 2017. Antioxidant, antigenotoxic, antimicrobial activities and phytochemical analysis of Dianthus carmelitarum. Records of Natural Products; 11(3).

3. Nimura, M, Kato, J, Mii, M. 2006. Interspecific hybrid production by reciprocal crosses between Dianthus caryophyllus L. and Dianthus $\times$ isensis Hirahata et Kitamura. The Journal of Horticultural Science and Biotechnology; 81(6), 995-1001.

4. Williams, EG, Rouse, JL. 1990. Relationships of pollen size, pistil length and pollen tube growth rates in Rhododendron and their influence on hybridization. Sexual Plant Reproduction; 3(1):7-17.

5. Jia, MX, Shi, Y, Di, W, Jiang, XR, Xu, J, Liu, Y. 2017. ROSinduced oxidative stress is closely related to pollen deterioration following cryopreservation. In Vitro Cellular and Developmental Biology-Plant; 53(4), 433-439.

6. Cetinbaş-Genç, A. 2019. Putrescine modifies the pollen tube growth of tea (Camellia sinensis) by affecting actin organization and cell wall structure. Protoplasma; 1-13.

7. Daher, FB, Chebli Y, Geitmann, A. 2009. Optimization of conditions for germination of cold-stored Arabidopsis thaliana pollen. Plant Cell Reports; 28(3), 347-357.

8. Beale, KM, Johnson, MA. 2013. Speed dating, rejection, and finding the perfect mate: advice from flowering plants. Current Opinion in Plant Biology; 16(5), 590-597.

9. Ylstra, B, Touraev, A, Moreno, RMB, Stöger, E, van Tunen, A. J., Vicente, O., Mol, JNM, Heberle-Bors, E. 1992. Flavonols stimulate development, germination, and tube growth of tobacco pollen. Plant Physiology; 100(2):902-907.

10. Wang, Q, Lu, L, Wu, X, Li, Y, Lin, J. 2003. Boron influences pollen germination and pollen tube growth in Picea meyeri. Tree Physiology; 23(5):345-351.

11. Wu, J, Shang, Z, Wu, J, Jiang, X, Moschou, PN, Sun, W, Roubelakis-Angelakis KA, Zhang S. 2010. Spermidine oxidasederived $\mathrm{H}_{2} \mathrm{O}_{2}$ regulates pollen plasma membrane hyperpolarizationactivated $\mathrm{Ca}_{2}{ }^{+}$-permeable channels and pollen tube growth. The Plant Journal; 63(6):1042-1053.
12. Vogler, F, Schmalzl, C, Englhart, M, Bircheneder, M, Sprunck, S. 2014. Brassinosteroids promote Arabidopsis pollen germination and growth. Plant Reproduction; 27(3):153-167.

13. Planas-Riverola, A, Gupta, A, Betegón-Putze, I, Bosch, N, Ibañes, M, Caño-Delgado, AI. 2019. Brassinosteroid signaling in plant development and adaptation to stress. Development; 146(5), dev151894.

14. Tanveer, M. 2019. Role of 24-Epibrassinolide in inducing thermo-tolerance in plants. Journal of Plant Growth Regulation; 1-11.

15. Maita, S, Sotomayor, C. 2015. The effect of three plant bioregulators on pollen germination, pollen tube growth and fruit set in almond [Prunus dulcis (Mill.) DA Webb] cvs. Non Pareil and Carmel. Electronic Journal of Biotechnology; 18(5), 381-386.

16. Khamsuk, O, Sonjaroon, W, Suwanwong, S, Jutamanee, K, Suksamrarn, A. 2018. Effects of 24-epibrassinolide and the synthetic brassinosteroid mimic on chili pepper under drought. Acta Physiologiae Plantarum; 40(6), 106

17. Singh, I, Shono, M. 2005. Physiological and molecular effects of 24-epibrassinolide, a brassinosteroid on thermotolerance of tomato. Plant Growth Regulation; 47(2-3), 111.

18. Thussagunpanit, J, Jutamanee, K, Kaveeta, L, Chai-Arree, W, Pankean, P, Suksamrarn, A. 2013. Effects of a brassinosteroid and an ecdysone analogue on pollen germination of rice under heat stress. Journal of Pesticide Science; D13-029.

19. Sotomayor, C, Castro, J, Velasco, N, Toro, R. 2012. Influence of seven growth regulators on fruit set, pollen germination and pollen tube growth of almonds. Journal of Agricultural Science and Technology; 2(9B):1051.

20. Gökbayrak, Z, Engin, H. 2018. Effects of foliar-applied brassinosteroid on viability and in vitro germination of pollen collected from bisexual and functional male flowers of pomegranate. International Journal of Fruit Science; 18(2), 226-230.

21. Brewbaker, JL, Kwack, BH. 1963. The essential role of calcium ion in pollen germination and pollen tube growth. American Journal of Botany; 9, 859-865.

22. Wu, Y, Qin, B, Feng, K, Yan, R, Kang, E, Liu, T, Shang, Z. 2018. Extracellular ATP promoted pollen germination and tube growth of Nicotiana tabacum through promoting $\mathrm{K}+$ and $\mathrm{Ca} 2+$ absorption. Plant Reproduction; 31(4):399-410.

23. Muhlemann, JK, Younts, TL, Muday, GK. 2018. Flavonols control pollen tube growth and integrity by regulating ROS homeostasis during high-temperature stress. Proceedings of the National Academy of Sciences; 115(47), E11188-E11197.

24. Wu, J, Qin, Y, Zhao, J. 2008. Pollen tube growth is affected by exogenous hormones and correlated with hormone changes in styles in Torenia fournieri L.. Plant Growth Regulation; 55(2):137-148.

25. Chhun, T, Aya, K, Asano, K, Yamamoto, E, Morinaka, Y, Watanabe, M, Kitano, H, Ashikari, M, Matsuoka, M, UeguchiTanaka, M. 2007. Gibberellin regulates pollen viability and pollen tube growth in rice. The Plant Cell, 19(12); 3876-3888.

26. Zhang, W, Sheng, J, Xu, Y, Xiong, F, Wu, Y, Wang, W, Wang, Z, Yang, J, Zhang, J. 2019. Role of brassinosteroids in rice spikelet differentiation and degeneration under soil-drying during panicle development. BMC Plant Biology; 19(1):1-16.

27. Hewitt, FR, Hough, T, O'Neill, P, Sasse, JM, Williams, EG, Rowan, KS. 1985. Effect of brassinolide and other growth regulators on the germination and growth of pollen tubes of Prunus avium using a multiple hanging-drop assay. Functional Plant Biology; 12(2), 201211 
Celal Bayar University Journal of Science

Volume 15, Issue 4, 2019 p 371-375

28. Engin, H, Gökbayrak, Z, Altunbas, D. 2015. Epibrassinolid, gibberellik asit ve naftalen asetik asittin bazı nar çeşitlerinde çiçek tozu çimlenme oranlarına etkisi. ÇOMÜ Ziraat Fakültesi Dergisi; 3(2), 19-25.

29. Engin, H, Gökbayrak, Z. 2016. In vitro pollen viability and germination of bisexual and functional male flowers of some Turkish pomegranate cultivars. Agriculture and Forestry; 62(4), 91-94.

30. Srinivasan, A, Saxena, N, Johansen, C. 1999. Cold tolerance during early reproductive growth of chickpea (Cicer arietinum L.) genetic variation in gamete development and function. Field Crop Research; 60(3): 209-222.
31. Liu, Z, Yuan, YL, Liu, SQ, Yu, XN, Rao, LQ. 2006. Screening for high-temperature tolerant cotton genotypes by testing in vitro pollen germination, pollen tube growth and boll retention. Journal of Integrative Plant Biology; 48(6), 706-714.

32. Ledesma, N, Sugiyama, N. 2005. Pollen quality and performance in strawberry plants exposed to high-temperature stress. Journal of the American Society for Horticultural Science; 130(3), 341-347. 